Rocznik Andragogiczny ANDRAGOGY YEARBOOK 2015

\title{
Ewa Skibińska (red.), Kariery zawodowe andragogów. Studium empiryczne, Wydawnictwo ITEE, Warszawa 2015, ss. 179.
}

Tradycja akademickiego kształcenia specjalistów edukacji dorosłych sięga okresu międzywojennego. Po 1945 r. ze względów ideologicznych redukowano edukację dorosłych do kształcenia szkolnego i zawodowego, studiów zaocznych i eksternistycznych. Nieliczne w skali kraju towarzystwa (np. Towarzystwo Uniwersytetów Ludowych, Towarzystwo Wiedzy Powszechnej), instytucje (np. uniwersytety ludowe, uniwersytety trzeciego wieku) zdane były w swojej działalności na entuzjastów, pasjonatów tego rodzaju pracy, którzy doskonalili się zawodowo najczęściej w toku pracy. W tym okresie jedyną formą akademickiego kształcenia specjalistów oświaty dorosłych były studia podyplomowe na Uniwersytecie Warszawskim z programem ogólnym i w Szkole Głównej Gospodarstwa Wiejskiego ze specjalistycznym programem dla nauczycieli szkół rolniczych i pozaszkolnej oświaty rolniczej. Przełom polityczny 1989 r. przyniósł odrodzenie się edukacji dorosłych w jej różnych formach organizacyjnych, ale także jako przedmiot badania i nauczania. W latach 90. XX w. wprowadzono do regularnego kształcenia akademickiego andragogikę, powołano też w kilku ośrodkach akademickich specjalność andragogiczną. Przemiany społeczno-gospodarcze kolejnych lat transformacji zweryfikowały potrzeby kształcenia w kierunku andragogicznym. Na Uniwersytecie Mikołaja Kopernika zlikwidowano specjalność „edukacja ustawiczna", na Uniwersytecie Łódzkim do edukacji dorosłych dodano "coaching”, na Uniwersytecie im. Adama Mickiewicza w Poznaniu zmieniono profil na „doradztwo zawodowe i personalne”, także w innych ośrodkach akademickich problematyka andragogiczna zawiera się najczęściej w doradztwie. Nieprzerwanie specjalność andragogiczna funkcjonuje na Uniwersytecie Warszawskim. Zespół pracowników Katedry Edukacji Ustawicznej i Andragogiki Wydziału Pedagogicznego UW, który prowadzi tę specjalność, przeprowadził badania na temat karier zawodowych absolwentów specjalności andragogicznej. Wyniki tego badania zostały zamieszczone w książce 
pt. Kariery zawodowe andragogów. Studium empiryczne pod redakcją Ewy Skibińskiej.

Na książkę składa się osiem tekstów, które przynoszą odpowiedź na postawione $\mathrm{w}$ badaniach pytania. Przedmiotem szczególnego zainteresowania był przebieg kariery zawodowej absolwentów specjalności andragogicznej. Kariera zawodowa absolwentów została usytuowana w szerokim kontekście edukacyjnym, obejmującym zarówno okres studiów (przygotowania do pracy), doświadczenia edukacyjne po zakończeniu studiów, jak też aspiracje i plany edukacyjne badanych. Innymi wątkami, które znalazły się w kręgu zainteresowań badaczy były: pierwsze doświadczenia zawodowe absolwentów, subiektywne poczucie sukcesu i porażki oraz definiowanie przez badanych kariery zawodowej. Materiał badawczy został zgromadzony za pomocą wywiadu częściowo kierowanego z przedstawicielami pokolenia $\mathrm{X}$ absolwentów z lat 1996-2006 oraz przedstawicieli pokolenia Y - absolwentów z lat 2008-2011.

W problematykę badawczą wprowadzają dwa teksty. Pierwszy: Transformacja uniwersytetu. Od limitowanego do szerokiego dostępu do studiów, od autoteliczności do ko modyfikacji wiedzy Krystyny Pleskot-Makulskiej zaspakaja dwie zasadnicze potrzeby potencjalnych czytelników, pokazuje ewolucję uniwersytetu i jego zmieniające się funkcje na tle społeczno-politycznym i ekonomicznym oraz wskazuje na współczesne sprzeczności oraz dylematy w tym kontekście.

Teoretyczną ramę badań stanowi koncepcja iksów i igreków jako pokoleniowych zbiorowości, która została zaprezentowana w kolejnym tekście przez Annę Marianowską. Autorka ukazała różnice i podobieństwa między tymi dwiema generacjami w Polsce i Ameryce, by następnie odnieść te charakterystyki do uczestników badania. Jak wynika z przeprowadzonej przez Autorkę analizy, wiele cech amerykańskiego pokolenia X i Y posiadają polskie pokolenia X i Y, tj. odpowiednio Pokolenie Końca Wieku oraz Europejscy Poszukiwacze. Rozbieżności dotyczą podejścia do początków kariery zawodowej i nastawienia do wykonywanej pracy.

Autorka kolejnego tekstu - Ewa Skibińska analizuje rozumienie pojęcia kariery zawodowej w ujęciu badanych absolwentów specjalności andragogicznej. Z analizy tej wynika, że najczęściej karierę zawodową traktują jako zmianę swojej pozycji społecznej na lepszą - wyższą w hierarchii pracowniczej lub wiążącą ją z coraz większymi kompetencjami, a tym samym z coraz szerszym zakresem odpowiedzialności zawodowej. Przy tym pokolenie Y Europejskich Poszukiwaczy traktuje sukces jako synonim kariery zawodowej. Natomiast pokolenie X - Pokolenie Końca Wieku zwraca większą uwa- 
gę na karierę poziomą, łącząc ją z poszerzaniem kompetencji zawodowych. Różnica ta wynikać też może z dłuższego stażu pracy, doświadczeń zawodowych i życiowych oraz większej refleksyjności związanej z wiekiem.

Ewa I. Kurek przedstawiła uwarunkowania wyborów edukacyjnych studentów - przyszłych andragogów oraz typologię absolwentów ze względu na prezentowany rodzaj aspiracji zawodowych. Z badań wynika, że różnice pokoleniowe między X i Y nie determinują jednoznacznie przynależności do wyróżnionych typów absolwentów, tj. 1) o stałych aspiracjach zawodowych; 2) o testujących aspiracjach edukacyjnych i 3) o chwiejnych aspiracjach edukacyjnych.

W kolejnym tekście Monika Gromadzka przedstawiła program kształcenia andragogicznego w świetle dokumentów uczelni oraz opinii absolwentów. Mamy zatem dwa, wzajemnie się uzupełniające źródła wiedzy o programie: obiektywne - dokumenty uczelni i subiektywne - wywiady $\mathrm{z}$ absolwentami. Autorka przedstawiła 25 lat historii programu kształcenia andragogów, pokazując przemiany programu specjalności i starania pracowników o dostosowanie go do potrzeb studentów, jak też rynku pracy. Następnie przedstawiła opinie pokolenia X i Y na temat programu oraz przebiegu kształcenia andragogicznego. Nie różnią się one znacznie od siebie - wszyscy chcą otrzymać konkretną, praktyczną wiedzę i narzędzia, które przydadzą się w pracy zawodowej. Słusznie Autorka tekstu zauważa, że taki dydaktyczny utylitaryzm niesie ze sobą też negatywne konsekwencje.

Pierwsze doświadczenia zawodowe badanych opisała Ewa Skibińska. Odniosła się w nim do motywów podejmowania pracy w czasie studiów, metod poszukiwania pracy, treści pierwszych doświadczeń zawodowych. Z badań wynika, że niezależnie od tego, jakiego rodzaju doświadczenia związane z pierwszym zatrudnieniem badani zebrali, stały się one cennym kapitałem $\mathrm{i}$ istotnym źródłem wiedzy osobistej czy zawodowej.

E. Dębska w tekście O andragogach na rynku pracy. Spetnione nadzieje, nieoczekiwane sukcesy, konstruowane biografie wykorzystuje koncepcję trzech typów biografii zawodowej: kotwica, patchwork, konstrukcja do interpretacji dróg zawodowych andragogów - absolwentów UW. Wzór kariery typu patchworka uzupełnia o karierę typu tranzycja. Każdy z wymienionych typów kariery został scharakteryzowany pod kątem przebiegu kariery, wzoru działania, zachowania oraz nastawienia do pracy, podejmowane działania, tożsamość zawodową, a także znaczenie pracy w życiu człowieka.

Tekst Zuzanny Wojciechowskiej dobrze zamyka całość rozważań zawartych w recenzowanej pozycji. Przedstawia rozumienie sukcesu i porażki w opinii badanych absolwentów specjalności andragogicznej. Autorka na 
podstawie zebranych danych wyróżniła kilka typów sukcesu: nieformalny, jako kreację oraz „na medal”. Następnie zaprezentowała porażki ujawnione przez nielicznych respondentów w kontekście cech indywidualnych respondentów i w sytuacjach wpływu otoczenia społecznego.

Tak oto dochodzimy do przedstawienia wniosków na temat recenzowanej pozycji. Jej wydanie jest cenne z kilku powodów. Przede wszystkim jest pierwszą w Polsce empiryczną analizą karier zawodowych specjalistów edukacji dorosłych, którą uznać można za wkład do profesjonalizacji tego obszaru edukacji i pracy zawodowej. Książka umożliwia też odniesienie się do dyskusji pierwszej połowy lat 90 . XX w. dotyczącej początku profesjonalizacji i przemian w tej dziedzinie na przestrzeni ostatnich 20 lat. Śledzenie losów absolwentów jest współcześnie wymogiem, którego celem jest weryfikowanie programu kształcenia w kontekście potrzeb pracodawców i rynku pracy, co trudno ignorować - prezentowana książka spełnia w pełni ten warunek. Mogą z zaprezentowanych w książce danych i wniosków skorzystać także inne jednostki oferujące kształcenie w kierunku andragogicznym. Wreszcie książka jest efektem pracy zespołowej, która integruje, uczy współpracy, rozwija naukowo w międzypokoleniowym dialogu, co jest wartością dla uczestniczących w niej osób, ale także przykładem dobrej praktyki dla innych. 